\title{
Knowledge and Practice Regarding Cervical Cancer Screening Among Women Attending Gynecology OPD, B.P. Koirala Institute of Health Sciences, Dharan, Nepal
}

\author{
Rai $\mathrm{G}^{1 *}$, Shrestha $\mathrm{M}^{2}$, Shah $\mathrm{T}^{3}$, Mandal $\mathrm{G}^{4}$, Agrawal $\mathrm{A}^{5}$, Bharati $\mathrm{M}^{6}$ \\ ${ }^{1}$ Associate, Department of Maternal Health Nursing, BPKIHS, Dharan, Nepal \\ ${ }^{2}$ Professor and Head, Department of Maternal Health Nursing, BPKIHS, Dharan, Nepal \\ ${ }^{3}$ Professor and Chief, Department of Community Health Nursing, College of Nursing BPKIHS, Dharan, Nepal \\ ${ }^{4}$ Professor, Department of Medical-Surgical Nursing, BPKIHS, Dharan, Nepal \\ ${ }^{5}$ Department of Obstetrics and Gynecology, BPKIHS, Dharan, Nepal \\ ${ }^{6}$ College of Nursing, Nepalese Army Institute of Health Sciences, Kathmandu, Nepal
}

*Corresponding Author

Rai G

\section{Article History}

Received: 22.08 .2020

Accepted: 29.08 .2020

Published: 06.09.2020

\begin{abstract}
Cervical cancer is the fourth most frequent cancer in women with an estimated 570,000 new cases in 2018 representing $6.6 \%$ of all female cancers. Cervical cancer is the leading cause of cancer death in women in low-HDI countries. Cervical cancer ranks first among the female cancer in Nepal with age-adjusted incidence rate 21.5, 2,942 new cases and 1,928 deaths. The high mortality rate from cervical cancer globally could be reduced through prevention, early diagnosis, effective screening and treatment. The study aim to identify the knowledge and practice of cervical cancer screening among women attending gynecology OPD. A descriptive cross-sectional study design was used in this study. Hundred and fifty women were selected through purposive sampling technique. A pretested semi structured interview schedule was used to measure research variables. Frequency, percentage, mean and chi-squired test were used to analyze the data. Out of 150 women, mean age was $39.41 \pm 10.26$ and $78.7 \%$ respondents were Hindu. More than three fourth $(84.7 \%)$ were literate. Slightly more than one third $(34.7 \%)$ of the respondents herd about cervical cancer screening. Among them, less than half $(46.2 \%)$ had adequate knowledge and only $8.7 \%$ of women had practice of cervical screening. There were no association between knowledge and socio-demographic variables but the practice were associated with residence $(\mathrm{p}=<0.05)$ and family income $(\mathrm{p}=<0.05$. A majority of women have inadequate knowledge and low practice of cervical cancer screening. Therefore cervical cancer screening and awareness program should be emphasized.
\end{abstract}

Keywords: Knowledge, Practice, Cervical, Cancer, Screening, Women.

\section{INTRODUCTION}

Cervical cancer is the fourth most frequent cancer in women with an estimated 570,000 new cases in 2018 representing $6.6 \%$ of all female cancers $[1,2]$ Cervical cancer ranks second in incidence and mortality behind breast cancer in lower HDI settings. The vast majority of which are in Sub-Saharan Africa and South-Eastern Asia. The highest regional incidence and mortality rates are seen in Southern Africa [2]. Cervical cancer is the leading cause of cancer death in women in low-HDI countries. Nearly $70 \%$ of cervical cancer deaths occur in South-Central Asia $(75,100$ deaths), Eastern Asia (54,500), and sub-Saharan Africa (76,400) [1]. India is the second most populous country in the world, accounts for almost 20\% (60,100) of cervical cancer deaths [2, 3]. According to WHO report 2018, cervical cancer ranks first among the female cancer in Nepal with age-adjusted incidence rate of 21.5 per 100,000 population, 2,942 new cases and 1,928 deaths [4]

Copyright @ 2020: This is an open-access article distributed under the terms of the Creative Commons Attribution license which permits unrestricted use, distribution, and reproduction in any medium for non commercial use (NonCommercial, or CC-BY-NC) provided the original author and source are credited. 
Currently, in many low resource settings, the disease is often not identified until it is further advanced or treatment is inaccessible resulting in a higher rate of death from cervical cancer. Understanding and detecting symptoms of cervical cancer can assist with early diagnosis. The high mortality rate from cervical cancer globally could be reduced through a comprehensive approach that includes prevention, early diagnosis, effective screening and treatment programmes. There are currently three vaccines that protect against common cancer-causing types of human papilloma virus and can significantly reduce the risk of cervical cancer [1].

According to world health organization, cervical cancer screening is the testing for precancer and cancer of women at risk, most of who will be without symptoms. At a minimum, screening is recommended for every woman 30 49 years of age at least once in a life time. Globally, in 2012, there were nearly a billion women between 30 and 49 years old, most of whom have never been screened even once in their life. Early detection and treatment of precancerous lesions can prevent the majority of cervical cancers. Three different types of tests are currently available: - Conventional (Pap) and liquid based cytology (LBC) — Visual inspection with Acetic Acid (VIA) - HPV testing for high risk HPV types (e.g. types 16 and 18). HPV vaccination does not replace cervical cancer screening. In countries where HPV vaccine is introduced, screening programmes may need to be developed or strengthened [5].

Various screening techniques have been introduced for early detection of cervical cancer in Nepal. For instance, Papanicolaou smear screening (cervical cytology) has been reported to be a good method for detecting early cervical cancer. Although the Papanicolaou test has been used as a primary method of screening in Nepal, feasibility of its introduction among the general population is often questioned due to restrictions in the present infrastructure and a lack of human and financial resources [6]. In Nepal, the national guideline for cervical cancer screening 2010 has prioritized prevention of cervical cancer through screening and has emphasized using the VIA approach for cervical cancer screening. The guideline has highlighted the need for integration of cervical cancer screening programs and prevention through national health policy and reproductive health programs. The integration of cervical cancer screening with regular health services could potentially increase the uptake of screening services [7].

Despite the cervical cancer screening and prevention has been a part of public screening program in Nepal, very few women receive screening services and they don't have sufficient knowledge about cervical cancer screening [8-12]. Hence, the study was conducted to identify the knowledge and practice of cervical cancer screening among women attending gynecology OPD.

\section{Material AND Methods}

Descriptive cross sectional research design was employed to identify the knowledge and practice of cervical cancer screening among women attending gynecology OPD, B.P. Koirala Institute of Health Sciences (BPKIHS), Dharan, Nepal. The study population was women attending Gynecology OPD, BPKIHS. Hundred and fifty women were selected through purposive sampling technique. Married women ages 21- 60 years old and willing to participate were included in the study. Self-developed semi-structured interview schedule was used to collect the data. Questionnaire based practice were identified as per their interview. Before proceeding data collection, ethical approval was obtained from Institutional review committee, BPKIHS, Dharan. Informed consent was taken from each subject. Privacy and confidentiality of subjects were maintained throughout the research process. Data were collected within 2 months of period. Nurses working Gynecological OPD and VIA clinic were trained for the data collection.

\section{Statistical Analysis}

The data were analyzed by using Statistical Package for Social Science (SPSS) version-15. Frequency, percentage were used to measure the socio-demographic and outcome variables. Chi-square test were used to find out association between socio-demographic and outcome variables. P-value was calculated and considered significant $\mathrm{p}=<0.05$. The analyzed data were presented in tables and graph according to the objectives of the study; demographic information, knowledge and practice regarding cervical cancer screening and association between selected variables with knowledge and practice regarding cervical cancer screening. Regarding the knowledge scoring, score of ' 1 ' was assigned for the correct response and ' 0 ' for incorrect response. Total score was calculated and the score was subdivided into two groups i.e. respondents having knowledge score $(<50 \%)$ was considered as inadequate knowledge and knowledge score $(\geq 50 \%)$ was considered as adequate knowledge. Regarding the practice scoring, score of ' 1 ' was assigned for their practice and ' 0 ' for not practice.

\section{RESUlTS AND DiSCUSSION}

Table-1 shows that more than half $(56 \%)$ of the women belong to age group 21 -39 years with mean age $39.41 \pm$ 10.27. Similarly, more than half (54\%) of women married below age 20 and majority $(67.3 \%)$ had $2-4$ children. Slightly more than half $(51.3 \%)$ of women were from V.D.C. Majority $(84.7 \%)$ of the women were literate, among them one third (33.9\%) were only can read and write. Majority (78.7\%) of women belong to Hindu. More than half (56\%) women used to live single family and majority (58.7\%) of women's family income was more than 20000 per month. 
Table-1: Socio-demographic Characteristics of Women $(\mathbf{n}=150)$

\begin{tabular}{|c|c|}
\hline Variables & Frequency $(\%)$ \\
\hline \multicolumn{2}{|l|}{ Age (years) } \\
\hline $21-39$ & $84(56.0)$ \\
\hline $40-59$ & $56(37.3)$ \\
\hline $60 \&$ above & $10(6.7)$ \\
\hline \multicolumn{2}{|l|}{ Age at marriage (years) } \\
\hline Below 20 & $81(54.0)$ \\
\hline $20 \&$ above & $69(46.0)$ \\
\hline \multicolumn{2}{|l|}{ Parity } \\
\hline Never give births & $9(6.0)$ \\
\hline Having one child & $26(17.3)$ \\
\hline Having 2-4 children & $101(67.3)$ \\
\hline Having $5 \&$ more children & $14(9.3)$ \\
\hline \multicolumn{2}{|l|}{ Address } \\
\hline Municipality & $72(48.7)$ \\
\hline V.D.C. & $77(51.3)$ \\
\hline \multicolumn{2}{|l|}{ Education } \\
\hline Illiterate & $23(15.3)$ \\
\hline Literate & $127(84.7)$ \\
\hline Can read and write & $43(33.9)$ \\
\hline Primary & $27(21.3)$ \\
\hline Lower secondary & $8(6.3)$ \\
\hline Secondary and above & $14(11.0)$ \\
\hline SLC and above & $35(27.6)$ \\
\hline \multicolumn{2}{|l|}{ Religion } \\
\hline Hindu & $118(78.7)$ \\
\hline Bauddha & $12(8.0)$ \\
\hline Kirat & $15(10.0)$ \\
\hline Christian & $3(2.0)$ \\
\hline Islam & $2(1.3)$ \\
\hline \multicolumn{2}{|l|}{ Family type } \\
\hline Single & $84(56.0)$ \\
\hline Joint & $66(44.0)$ \\
\hline \multicolumn{2}{|l|}{ Income (per month) } \\
\hline Less than 20000 & $62(41.3)$ \\
\hline $20000 \&$ above & $88(58.7)$ \\
\hline
\end{tabular}

Figure-1 shows that total of 150 women slightly more than one third $(34.7 \%)$ of the women had knowledge about cervical cancer screening. Figure 2 reveals that below half $(40.4 \%)$ of women got information from media followed by family/Friends (25\%), health workers (19.2), course book/Newspaper (15.4).

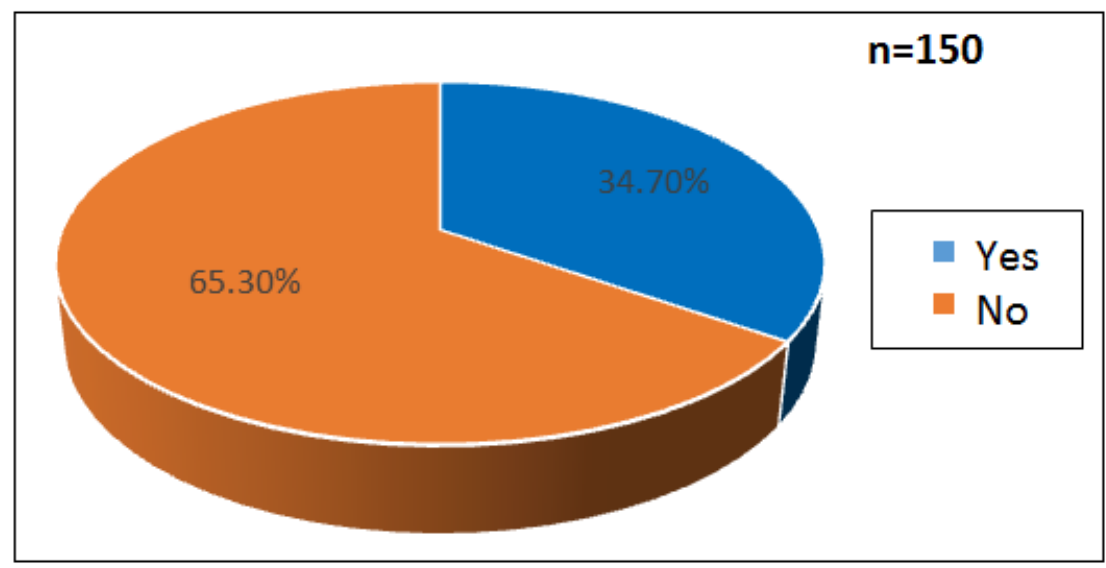

Fig-1: Women's Knowledge Regarding Cervical Cancer Screening 


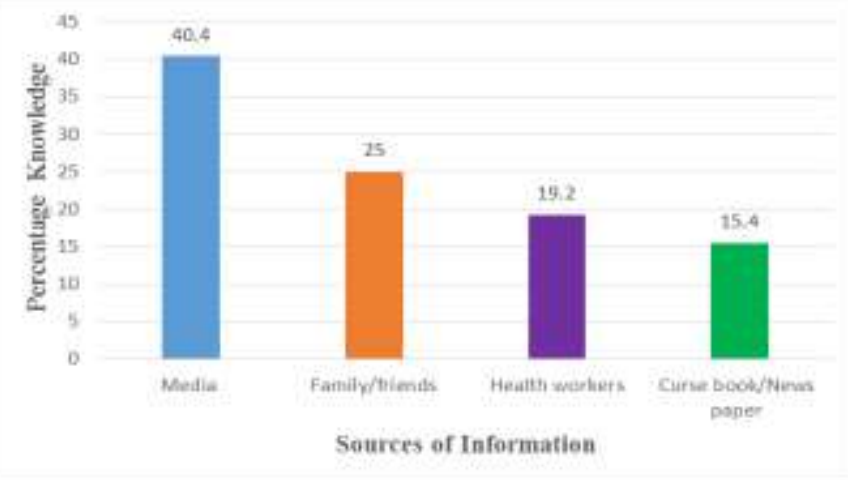

Fig-2: Sources of Information about Cervical Cancer Screening

Table-2: Women's Knowledge Regarding Cervical Cancer, Methods and Frequency of Cervical Cancer Screening $\mathbf{n}=52$

\begin{tabular}{|c|c|c|}
\hline Description & Yes $(\%)$ & No $(\%)$ \\
\hline \multicolumn{3}{|l|}{ Cervical cancer } \\
\hline Heard about cervical cancer & $45(86.5)$ & $7(13.5)$ \\
\hline Risk factors of cervical cancer & $40(76.9)$ & $12(23.1)$ \\
\hline Treatment outcome is good if early detected & $38(73.1)$ & $14(26.9)$ \\
\hline Prognosis of cervical cancer & $25(48.1)$ & $27(51.9)$ \\
\hline \multicolumn{3}{|l|}{ Cervical cancer screening } \\
\hline Cervical cancer screening is done to identify changes in cervix & $26(50.0)$ & $26(50.0)$ \\
\hline Pap smear is acceptable cervical cancer screening & $19(36.5)$ & $33(63.5)$ \\
\hline \multicolumn{3}{|l|}{ Methods of Cervical Cancer Screening } \\
\hline Pap smear & $24(46.2)$ & $28(53.8)$ \\
\hline Visual Inspection of Acetic Acid (VIA) & $32(61.5)$ & $20(38.5)$ \\
\hline \multicolumn{3}{|l|}{ Frequency of Pap smear } \\
\hline Women ages $21-29$ years in every 3 yrs. & $19(36.5)$ & $33(63.5)$ \\
\hline Women ages $30-65$ years in every (3-5) yrs. with cytology & $18(34.6)$ & $34(65.4)$ \\
\hline Women ages $\geq 65$ should discontinue screening & $42(80.8)$ & $10(19.10)$ \\
\hline \multicolumn{3}{|l|}{ Reasons for more frequent Pap smear } \\
\hline Diagnosed case of cervical cancer or precancerous cell Present in Pap smear & $38(73.1)$ & $14(26.9)$ \\
\hline Weakened immune system due to organ transplant, chemotherapy or chronic corticosteroid use & $16(30.8)$ & $36(69.2)$ \\
\hline HIV infection & $19(36.5)$ & $33(63.5)$ \\
\hline History of smoking & $22(42.3)$ & $30(57.7)$ \\
\hline \multicolumn{3}{|l|}{ Visual inspection with acetic acid (VIA) } \\
\hline It is a visual examination of the uterine cervix after application of 3-5\% acetic acid & $8(15.4)$ & $44(84.6)$ \\
\hline VIA determines incidence of precancerous lesions of cervix & $14(26.9)$ & $38(73.1)$ \\
\hline Recommended age of women for VIA is $30-60 \mathrm{yrs}$. & $17(32.7)$ & $35(67.3)$ \\
\hline VIA should be done in every 5 years of interval once the negative result & $15(28.8)$ & $37(71.2)$ \\
\hline \multicolumn{3}{|l|}{ Availability of VIA health facilities } \\
\hline Mobile VIA Clinic & $35(67.3)$ & $17(32.7)$ \\
\hline Primary Health Care Center & $28(53.8)$ & $24(46.2)$ \\
\hline District Hospital & $33(63.5)$ & $19(36.5)$ \\
\hline Zonal/regional/Center & $34(65.4)$ & $18(34.6)$ \\
\hline Tertiary Care Hospital/Cancer Hospital & $33(63.5)$ & $19(36.5)$ \\
\hline
\end{tabular}

Table-2 depicts women's knowledge regarding cervical cancer screening, the subsequent questions of knowledge portion were asked to 52 in respondents who heard about cervical cancer screening. Among them majority $(86.5 \%)$ have heard about cervical cancer and $76.9 \%$ of women had knowledge about risk factors. Less than half (48.1\%) of women had knowledge about prognosis of cervical cancer. Half $(50 \%)$ of them mentioned cervical screening is done to identify changes in the cervix but majority (63.5\%) did not have idea about Pap smear is acceptable cervical cancer screening. Regarding methods of cervical screening, more than half $(53.8 \%)$ of women didn't have knowledge about Pap smear but majority $(63.5 \%)$ had idea about VIA. Similar portions $(63.5 \%, 65.4 \%)$ did not have knowledge about frequency of screening for women ages 21-29 in every 3 yrs. and women ages 30-65 years in every (3-5) yrs. with cytology respectively. Majority $(80.8 \%)$ of women mentioned women ages $>65$ should discontinue screening. Regarding the reasons for more frequent Pap smear, majority (73.1\%) mentioned diagnosed case of cervical cancer or a case with precancerous cells showed in Pap smear need more frequent pap smear. But they did not have knowledge about weakened immune system (69.2\%), HIV infection (63.5\%) and history of smoking (57.7\%) need frequent Pap smear. Majority $(84.6 \%)$ did not have knowledge about VIA is done with 3-5\% acetic acid. Majority (73.1\%) didn't have 
knowledge about VIA determines precancerous lesion of cervix. Similarly majorities $(67.3 \%, 71.2 \%)$ did not have knowledge about recommended age group is ages 30- 60 years for VIA and frequency of VIA in every 5 years respectively. Majority (82.7\%) of women had knowledge about health facilities where availability of VIA. Among them most of the responded that VIA is available in mobile VIA clinic $(67.3 \%)$ primary health care center $(53.8 \%)$, district hospital (63.5\%), Zonal/Regional hospital (65.4\%) and tertiary care hospital/cancer hospital (63.5\%).

Table-3: Women's Practice Regarding Cervical Cancer Screening

\begin{tabular}{|l|l|}
\hline Description & Frequency (\%) \\
\hline Cervical screening (n=150) & $13(8.7)$ \\
\hline Done & $137(91.3)$ \\
\hline Not done & $6(46.2)$ \\
\hline Types of cervical screening (n=13) \\
\hline PAP smear & $7(53.8)$ \\
\hline Visual Inspection with Acetic acid & \\
\hline Pap Screening result (n=6) & $6(100.0)$ \\
\hline Negative & $0(0.0)$ \\
\hline Positive & $6(100.0)$ \\
\hline Time duration of Pap $(\mathbf{n}=\mathbf{6})$ & $0(0.0)$ \\
\hline Less than 5 years & $7(100.0)$ \\
\hline Five years \& more & $0(0.0)$ \\
\hline VIA Screening result $(\mathbf{n}=\mathbf{7})$ & $7(100.0)$ \\
\hline Negative & $0(0.0)$ \\
\hline Positive & \\
\hline Time duration of VIA $(\mathbf{n}=7)$ & \\
\hline Less than 5 years & \\
\hline Five years \& more &
\end{tabular}

Table- 3 shows that out of 150 , only $8.7 \%$ of women had practice of cervical cancer screening. Among them, practice of Pap smears were below half (46.2\%) and visual inspection with acetic acid (53.8\%). All (100\%) of women had negative Pap smear and VIA test results. All (100\%) Pap smear and VIA test were done within five years.

Table-4: Association between Knowledge and Socio-Demographic Variables $(\mathbf{n}=52)$

\begin{tabular}{|c|c|c|c|}
\hline \multirow[t]{2}{*}{ Socio-demographic variable } & \multicolumn{3}{|c|}{ Knowledge } \\
\hline & Adequate F (\%) & Inadequate $\mathbf{F}(\%)$ & P-value \\
\hline \multicolumn{4}{|l|}{ Age (years) } \\
\hline $21-39$ & $17(54.8)$ & $14(45.2)$ & \multirow[t]{2}{*}{0.127} \\
\hline $40-65$ & $7(33.3)$ & $14(66.7)$ & \\
\hline \multicolumn{4}{|l|}{ Age at marriage (years) } \\
\hline Below 20 & $9(34.6)$ & $17(65.4)$ & \multirow[t]{2}{*}{0.164} \\
\hline 20 and above & $15(57.7)$ & $11(42.3)$ & \\
\hline \multicolumn{4}{|l|}{ Having Children } \\
\hline $0-3$ children & $21(53.8)$ & $18(46.2)$ & \multirow[t]{2}{*}{$0.064 \mathrm{~F}$} \\
\hline $4 \&$ more Children & $3(23.1)$ & $10(62.5)$ & \\
\hline \multicolumn{4}{|l|}{ Residence } \\
\hline Municipality & $15(53.6)$ & $13(46.4)$ & \multirow[t]{2}{*}{0.246} \\
\hline VDC & $9(37.5)$ & $15(62.5)$ & \\
\hline \multicolumn{4}{|l|}{ Education } \\
\hline Illiterate & $0(0.0)$ & $4(100.0)$ & \multirow[t]{2}{*}{$0.115 \mathrm{~F}$} \\
\hline Literate & $24(50.0)$ & $24(50.0)$ & \\
\hline \multicolumn{4}{|l|}{ Occupation } \\
\hline House maker & $15(39.5)$ & $23(60.5)$ & \multirow[t]{2}{*}{0.111} \\
\hline Service holder \& others & $9(64.3)$ & $5(35.7)$ & \\
\hline \multicolumn{4}{|l|}{ Religion } \\
\hline Hindu & $15(40.5)$ & $22(59.5)$ & \multirow[t]{2}{*}{0.202} \\
\hline Non Hindu & $9(60.0)$ & $6(40.0)$ & \\
\hline \multicolumn{4}{|l|}{ Family type } \\
\hline Single & $11(42.3)$ & $15(57.7)$ & \multirow[t]{2}{*}{0.578} \\
\hline Joint & $13(50.0)$ & $13(50.0)$ & \\
\hline \multicolumn{4}{|l|}{ Income (per month) } \\
\hline Less than 20000 & $16(55.2)$ & $13(44.8)$ & \multirow[t]{2}{*}{0.143} \\
\hline $20000 \&$ above & $8(34.8)$ & $15(65.2)$ & \\
\hline
\end{tabular}

Note: level of significant considered $\mathrm{p}=0.05, \mathrm{~F}=$ Fishers exact test 
Table-4 reveals that there were no statistical association in knowledge regarding cervical cancer screening with age $(\mathrm{p}=0.127)$, age at marriage $(\mathrm{p}=0.164)$, having children $(\mathrm{p}=0.064)$, residence $(\mathrm{p}=0.246)$, education $(\mathrm{p}=0.115)$, occupation $(\mathrm{p}=0.111)$, religion $(\mathrm{p}=202)$, family type $(\mathrm{p}=0.578)$ and income of the family $(\mathrm{p}=0.143)$. Table-5 shows that there are statistical association in practice of cervical cancer screening with residence $(\mathrm{p}=0.008)$ and family income $(\mathrm{p}=0.008$. But there are no statistical association found between practice of cervical cancer screening and age $(\mathrm{p}=0.389)$, age at marriage $(\mathrm{p}=0.260)$, having children $(\mathrm{p}=0.039)$, education $(\mathrm{p}=0.220)$, occupation $(\mathrm{p}=0.155)$, religion $(\mathrm{p}=0.115)$ and family type $(\mathrm{p}=0.454)$

Table-5: Association between Practice and Socio-Demographic Variables $(\mathbf{n}=150)$

\begin{tabular}{|c|c|c|c|}
\hline \multirow[t]{2}{*}{ Socio-demographic variable } & \multicolumn{3}{|c|}{ Practice } \\
\hline & Yes F (\%) & No F (\%) & P-value \\
\hline \multicolumn{4}{|l|}{ Age (years) } \\
\hline $21-39$ & $9(10.7)$ & $76(89.3)$ & \multirow[t]{2}{*}{0.389} \\
\hline $40-65$ & $4(6.1)$ & $61(93.9)$ & \\
\hline \multicolumn{4}{|l|}{ Age at marriage (years) } \\
\hline Below 20 & $5(6.2)$ & $76(93.8)$ & \multirow[t]{2}{*}{$0.260 \mathrm{~F}$} \\
\hline 20 and above & $8(11.6)$ & $61(88.4)$ & \\
\hline \multicolumn{4}{|l|}{ Having Children } \\
\hline $0-3$ children & $13(11.6)$ & $99(88.4)$ & \multirow[t]{2}{*}{$0.039 \mathrm{~F}$} \\
\hline $4 \&$ more Children & $0(0.0)$ & $38(100.0)$ & \\
\hline \multicolumn{4}{|l|}{ Residence } \\
\hline Municipality & $11(15.1)$ & $62(84.9)$ & \multirow[t]{2}{*}{$0.008 \mathrm{~F}$} \\
\hline VDC & $2(2.6)$ & $75(97.4)$ & \\
\hline \multicolumn{4}{|l|}{ Education } \\
\hline Illiterate & $0(0.0)$ & $23(100.0)$ & \multirow[t]{2}{*}{$0.220 \mathrm{~F}$} \\
\hline Literate & $13(10.2)$ & $114(89.8)$ & \\
\hline \multicolumn{4}{|l|}{ Occupation } \\
\hline House maker & $8(6.9)$ & $108(93.1)$ & \multirow[t]{2}{*}{0.155} \\
\hline Service holder \& others & $5(14.7)$ & $29(85.3)$ & \\
\hline \multicolumn{4}{|l|}{ Religion } \\
\hline Hindu & $8(6.8)$ & $110(93.2)$ & \multirow[t]{2}{*}{0.115} \\
\hline Non Hindu & $5(15.6)$ & $27(84.4)$ & \\
\hline \multicolumn{4}{|l|}{ Family type } \\
\hline Single & $6(7.1)$ & $78(92.9)$ & \multirow[t]{2}{*}{0.454} \\
\hline Joint & $7(10.6)$ & $59(89.4)$ & \\
\hline \multicolumn{4}{|l|}{ Income (per month) } \\
\hline Less than 20000 & $10(16.1)$ & $52(83.9)$ & \multirow[t]{2}{*}{$0.008 \mathrm{~F}$} \\
\hline $20000 \&$ above & $3(3.4)$ & $85(96.6)$ & \\
\hline
\end{tabular}

Note: level of significant considered $\mathrm{p}=0.05, \mathrm{~F}=$ Fishers exact test

\section{DISCUSSION}

Though the national guideline for cervical cancer screening and prevention in Nepal was formulated in 2010 with coverage goal of $50 \%$ in next five years [7], majorities of the study's findings suggested that accessibility, acceptability and coverage of cervical cancer screening is still low along with low public awareness. Cervical cancer screening program had many difficulties in terms of limited medical services, difficult geographical terrain creating difficulties in delivering health services [13].

The current study showed that slightly more than one third $(34.7 \%)$ of the women had knowledge about cervical cancer screening (Figure-1). Among them, less than half $(46.2 \%)$ had adequate knowledge and only $8.7 \%$ of women had practice of cervical screening (Table 3) Slightly more than half $(53.8 \%)$ of the women didn't have knowledge about Pap smear but majority $(63.5 \%)$ had idea about VIA.. There were no association between knowledge and socio-demographic variables but the practice were associated with residence $(p=<0.05)$ and family income $(p=<0.05$. Due to the a few numbers of women who practiced cervical cancer screening, this could not be real significant association.

The findings are consistent with various studies findings from Nepal, where insufficient knowledge and practice about cervical cancer screening were revealed except significant association observed in some of the socio-demographic variables i.e. education, ethnicity and positive family history of cancer [8-12]. Study conducted by Thapa $M$ [8] on cervical cancer awareness and practice of Pap smear test among women with gynecological problems revealed that only 
$39 \%$ of women were aware of Pap smear test. Pap smear test coverage was $16.6 \%$ in studied population. Main reason of not doing Pap smear test was lack of knowledge of the test. High educational status of the women had significant positive impact on knowledge of cancer cervix and practice of Pap smear test [8]. Study findings of Bansal AB et al., reported only $34.5 \%$ participants had heard about cervical screening and $9.5 \%$ actually underwent screening test, Binary logistic regression analysis revealed that education age and income were independent predictors of better knowledge and practice depends on age, income, and marital status [14].

Various studies findings from India are in contrast with the current study findings. There were observed somehow improvement in knowledge and practice of cervical cancer screening. The study of Shrestha BK et al., where, majority $(58.1 \%)$ of the respondents had good knowledge in cervical cancer screening and $66.4 \%$ of the respondent accepted Pap smear test. Study showed the association between respondents knowledge of cervical cancer screening with educational status $(\mathrm{p}=0.04)$, religion $(\mathrm{p}=0.01)$ at 0.05 level of significance [15]. A study from India by Narayana $\mathrm{G}$ et al., revealed that most $(74.6 \%)$ of the respondents had heard about cervical cancer and majority of them are heard from media (41.6\%). Most women knew symptoms (64.2\%), risk factors $(62.7 \%)$, screening methods (76.9\%), and preventive measures $(61.7 \%)$ for cervical cancer. Various studies findings from India and some of the study findings from Nepal are in contrast with the current study findings more than three-fourth of women $(86.6 \%)$ are not having practice toward cervical cancer screening. Socio-demographic characteristics are strongly associated with KAP levels [16]. A study of Dahiya N et al., from New Delhi India showed that only 39 women (26\%) had ever heard of cervical cancer screening. Only 27 women (18.0\%) ever had Pap smear done in the past and 87 women $(58.0 \%)$ were willing to undergo cervical cancer screening offered free of cost [17].

\section{CONCLUSION}

The findings indicated that insufficient knowledge and practice of cervical cancer screening. Not any of the socio-demographic variables found as the predictor of knowledge and practice. Therefore cervical cancer screening awareness program along with service delivery should be emphasized.

\section{ACKNOWLEDGEMENT}

The authors acknowledge B.P. Koirala Institute of Health Sciences, Dharan for providing fund to conduct study and study participants for providing data. Authors are grateful to the Mrs. Mahima Tuladhar, OPD Incharge and Mrs. Pujan Subba, ANM for providing supports in data collection. Authors appreciate the supports from staffs of College of Nursing.

\section{REFERENCES}

1. WHO. (2018). Cervical cancer an overview. Retrieved August 16, 2018, from www.who.int > cancer > prevention > diagnosis-screening.

2. Bray, F., Ferlay, J., Soerjomataram, I., Siegel, R. L., Torre, L. A., \& Jemal, A. (2018). Global cancer statistics 2018: GLOBOCAN estimates of incidence and mortality worldwide for 36 cancers in 185 countries. CA: a cancer journal for clinicians, 68(6), 394-424.

3. American Cancer Society. (2018). Global Cancer Facts and Figures, 4th Edition. Retrieved April 16, 2019, from https://www.cancer.org/research/cancer-facts-statistics/global.html

4. GLOBOCAN. (2018). Nepal-Global Cancer Observatory: Nepal factsheet. In: International Agency for Research on Cancer, World Health Organization. Retrieved April 28, 2019, from http:/gco.iarc.fr/today/data/factsheets/ populations/524-nepal-fact-sheets.pdf

5. WHO. (2013). Guidance Note. Key facts about cervical cancer screening and treatment. Comprehensive cervical cancer prevention and control: a healthier future for girls and women. Retrieved August 20, 2018, from https://apps.who.int/iris/handle/10665/78128

6. Gyawali, B., Keeling, J. J., van Teijlingen, E., Dhakal, L., \& Aro, A. R. (2015). Cervical cancer screening in Nepal: ethical considerations. Medicolegal and Bioethics. 5:1-6.

7. Family Health Division. (2010). National Guideline for Cervical Cancer Screening and Prevention in Nepal. Department of Health Services, Kathmandu: Government of Nepal.

8. Thapa, M. (2018). Cervical Cancer Awareness and Practice of Pap Smear Test Among Women with Gynecological Problems. JAMA. 56(211), 654-657.

9. Thapa, N., Maharjan, M., Petrini, M. A., Shah, R., Shah, S., Maharjan, N., ... \& Cai, H. (2018). Knowledge, attitude, practice and barriers of cervical cancer screening among women living in mid-western rural, Nepal. Journal of gynecologic oncology, 29(4):1-12.

10. Shrestha, S., \& Dhakal, P. (2017). Knowledge, attitude and practice regarding cervical cancer screening among women attending a teaching hospital, Bharatpur, Chitwan. Journal of family \& reproductive health, 11(1), 18-23. 
11. Sherpa, A. T., Karki, B. S., Sundby, J., Nygard, M., Franceschii, S., \& Clifford, G. (2015). Population based study of cervical cancer screening in Bharatpur, Nepal. Journal of Manmohan Memorial Institute of Health Sciences, 1(4), 3-8.

12. Shrestha, J., Saha, R., \& Tripathi, N. (2013). Knowledge, attitude and practice regarding cervical cancer screening amongst women visiting tertiary centre in Kathmandu, Nepal. Nepal Journal of Medical Sciences, 2(2), 85-90.

13. Joshi, M., \& Mishra, S. R (2013). Cervical Cancer Screening in Nepal. Health Prospect Journal of Public Health, 12(1) I May-Aug. Retrieved from http://www.nphss.org.np/jhprospect

14. Bansal, A. B., Pakhare, A. P., Kapoor, N., Mehrotra, R., \& Kokane, A. M. (2015). Knowledge, attitude, and practices related to cervical cancer among adult women: A hospital-based cross-sectional study. Journal of natural science, biology, and medicine, 6(2), 324-328.

15. Shrestha, B. K., Sapkota, D. K., \& Sapkota, M. (2019). Knowledge and Acceptability of Cervical Cancer Screening among Adult Women Visiting in Gynecological OPD. Journal of College of Medical Sciences-Nepal, 15(1), 67-70.

16. Narayana, G., Suchitra, M. J., Sunanda, G., Ramaiah, J. D., Kumar, B. P., \& Veerabhadrappa, K. V. (2017). Knowledge, attitude, and practice toward cervical cancer among women attending Obstetrics and Gynecology Department: A cross-sectional, hospital-based survey in South India. Indian journal of cancer, 54(2), 481-487.

17. Dahiya, N., Aggarwal, K., Singh, M. C., Garg, S., \& Kumar, R. (2019). Knowledge, attitude, and practice regarding the screening of cervical cancer among women in New Delhi, India. Tzu-Chi Medical Journal, 31(4), $240-243$. 